\title{
Application Height in Herbicides Efficiency in Bean CROPS ${ }^{1}$
}

\author{
Altura de Aplicação na Eficiência de Herbicidas na Cultura do Feijão \\ PEREIRA, G.A.M. ${ }^{2}$, BARCELLOS JR., L.H. ${ }^{2}$, SILVA, D.V. ${ }^{3}$, BRAGA, R.R. ${ }^{2}$, TEIXEIRA, M.M. ${ }^{2}$, \\ SILVA, A.A. ${ }^{2}$, and RIBEIRO JR., J.I. ${ }^{2}$
}

\begin{abstract}
Inadequate herbicide application can result in failures in weed control and/or poisoning of the crops, resulting in yield losses. In this research were assessed the effects of the sprayer nozzle boom height in the distribution of the spray solution for weed control, influencing intoxication of beans and crop yield. Experiments were conducted in laboratory and field conditions. In laboratory, the performance of flat spray tip TT 11002 was assessed at heights $0.20,0.30,0.40$ and 0.50 meters with respect to the target surface. In the field the same heights were assessed in applications of herbicides fomesafen, fluazifop-P-butyl and fomesafen + fluazifop-P-butyl. There was an inverse relationship between the height of the spray boom and the coefficients of variation of the patterns. The mixture better efficiency in a tank of fluazifop-P-butyl + fomesafen was obtained with the height of $0.50 \mathrm{~m}$ from the target. This treatment resulted in better weed control, lower poisoning of the bean plants and better crop yield rates.
\end{abstract}

Keywords: Phaseolus vulgaris, application technology, mixture of herbicides.

RESUMO - Aplicações de herbicidas de forma inadequada podem resultar em falhas no controle das plantas daninhas e/ ou intoxicação da cultura, ocasionando em perda de produtividade. Nesta pesquisa foram avaliados os efeitos da altura da barra porta-bicos na distribuição da calda para o controle de plantas daninhas, influenciando a intoxicação do feijoeiro e a produtividade da cultura. Foram realizados experimentos em condições de laboratório e de campo. Em laboratório, avaliou-se o desempenho das pontas de pulverização TT 11002 de jato plano nas alturas de 0,20, 0,30, 0,40 e $0,50 \mathrm{~m}$, em relação à superficie do alvo. No campo, as mesmas alturas foram avaliadas nas aplicações dos herbicidas fomesafen, fluazifop-p-butil e fomesafen + fluazifop-p-butil. Observou-se relação inversa entre a altura da barra e o coeficiente de variação dos perfis. Melhor eficiência da mistura em tanque de fluazifop-p-butil + fomesafen foi obtida com altura de 0,50 m do alvo. Este tratamento resultou em melhor controle das plantas daninhas, menor intoxicação do feijoeiro e melhores indices produtivos da cultura.

Palavras-chave: Phaseolus vulgaris, tecnologia de aplicação, mistura de herbicidas.

\section{INTRODUCTION}

Brazil, despite being the largest producer of Phaseolus vulgaris, has a low average yield of this herbaceous annual plant (Conab, 2014). Among the various reasons for the low bean yield, inadequate tilling of weeds is of great importance. Several studies made by Wilson et al. (1993), Salgado et al. (2007) and Borchartt et al. (2011) confirm that weeds can promote losses of up to $93 \%$ of bean grains yield. These losses are dependent on the weed species, the density of infestation, environmental factors and the interaction period between the species. To avoid such losses, it is necessary that the weeds be controlled in an efficient manner during crop tillage. Due to its advantages over mechanical methods (greater

1 Recebido para publicação em 9.3.2015 e aprovado em 16.3.2015.

2 Universidade Federal de Viçosa, Viçosa, MG, Brasil, <gustavogamp@hotmail.com>; ${ }^{3}$ Universidade Federal Rural do Semi-árido, Mossoró, RN, Brasil. 
efficiency, lower cost and less dependence on labor), most farmers use a chemical method for controlling weeds. However, for this method to be effective, it is necessary that the application technology be suited to the herbicide characteristics, the crop and the weeds to be controlled.

Most of the time, much importance is given to the product to be applied and little importance to the application technique. It is not enough to know the product, but it is also important to know the application method. It is necessary to ensure that the product efficiently reach the target, minimizing losses. For this, the uniformity of application and an appropriate droplet spectrum are needed (Cunha et al., 2007).

In bean crops, weed control, most often, is carried out with the application of the mixture in the tank of herbicides fluazifop-P-butyl and fomesafen (Jakelaitis et al., 2006; Manabe et al., 2014). Fluazifop-P-butyl acts by inhibiting Acetyl-CoA (Acetyl coenzyme A or acetyl-CoA) carboxylase (ACC) enzyme, preventing lipid synthesis in plants (Silva \& Silva, 2007). It controls with high efficiency grass plants originating from seeds (Silveira et al., 2012). Fomesafen causes the inhibition of protoporphyrinogen oxidase enzyme and efficiently controls dicotyledonous weeds early in their development (Silva \& Silva, 2007). The mixture (fluazifop-P-butyl + fomesafen) is designed to control grasses and dicotyledons that occur in most bean crops in Brazil. Machado et al. (2006) confirm the agronomic efficiency of this mixture. However, reports of cases of failure in the application of those herbicides are common in the field, resulting in poisoning of crops or failures in weed control. It is believed that the majority of failures are caused by faults in the application technology adopted, since the technology level used at the time of application of any crop protection can determine its effectiveness. The uniform distribution of the spray solution is given by the assembling conditions and equipment operation, such as nozzle spacing, boom height, opening angle of tips and work pressure (Perecin et al., 1994; Bauer \& Raetano, 2004). Inadequate sprayer nozzle boom heights can promote herbicide selectivity loss by the crops caused by the increased dosage resulting from the poor formation of the distribution pattern.

Several studies have reported changes in the distribution pattern caused by incorrect use of the height of the spray boom (Bauer \& Raetano, 2004; Freitas et al., 2005; Cunha \& Ruas, 2006; Cunha \& Silva, 2010). Thus, the aim of this study was to assess the effects of the herbicides application boom height in the distribution of the spray solution in weed control and yield bean plants rates.

\section{MATERIALS AND METHODS}

To assess the performance of spray nozzles, assays were performed in a laboratory using a bench constructed in accordance with ISO 5682/ 1 standard for determination of the flow rate and uniformity of hydraulic spray tips volumetric distribution. This bench is $2.0 \mathrm{~m}$ long by $1.0 \mathrm{~m}$ wide with $\mathrm{V}$-shaped channels measuring 0.05 meters width and length. The hydraulic pressure was produced by a piston pump with maximum flow rate of $20 \mathrm{~L} \mathrm{~min}^{-1}$ and maximum pressure of $500 \mathrm{kPa}$, powered by an electric motor of $220 \mathrm{~V}$, and power equal to $2.2 \mathrm{~kW}$. The bench also has a system to regulate the pressure and filtering of the liquid and a sprayer nozzle boom with seating for four nozzles. The boom working height may vary in the range from 0.10 to $0.70 \mathrm{~m}$. In the central part of the spray boom, a pressure gauge was fixed with a precision of $99.5 \%$, from which is monitored the pressure at which the tested tips were subjected to. For measuring the flow and application range, 32 measuring cylinders were used, with a capacity of $250 \mathrm{~mL}$ and an accuracy equivalent to $2 \mathrm{~mL}$.

Four spray tips, flat spray tip TT 11002 , were installed together, spaced every $0.50 \mathrm{~m}$ on heights $0.20,0.30,0.40$ and $0.50 \mathrm{~m}$ from the table surface, being submitted to a pressure of $300 \mathrm{kPa}$ with spray solution spraying with water and bright blue dye (FDC-1).

To obtain the volumetric distribution and coefficient of variation, samples were taken from the sprayed liquid for one minute, followed by readings of the volumes contained in each cylinder; the process was repeated three times. 
The distribution uniformity was measured in accordance with the volume collected in the test tubes of the bench, by means of the coefficient of variation calculated according to Equation 1.

$$
C V=\frac{S}{\bar{X}}
$$

where: $\mathrm{CV}=$ coefficient of variation $(\%) ; S=$ standard deviation $(\mathrm{mL})$; and $\bar{x}=$ average volume of observed values $(\mathrm{mL})$.

The distribution patterns of the tips were represented by means of graphs plotted with volume and position data.

The field trial was done from September 2013 to January 2014 in the Brazilian city Viçosa, in a clayey soil classified as Alfisol (Table 1). The climate of the region is humid subtropical, with dry winters and hot summers, according to Köppen-Geiger classification adapted to Brazil (Nóbrega, 2010); the average annual temperature is $21^{\circ} \mathrm{C}$ and the average annual rainfall is $1,200 \mathrm{~mm}$.

The bean plant was grown in a notillage system, and the preparation of the experimental area was carried out by drying the vegetation 15 days before planting, by the application of the glyphosate herbicides tank mixture $\left(1,080 \mathrm{~g} \mathrm{ha}^{-1}\right)+2,4-\mathrm{D}(2,4-$ Dichlorophenoxyacetic acid) (540 $\left.\mathrm{g} \mathrm{ha}^{-1}\right)$. The sowing of the pinto bean (in Brazil, "carioca bean") variety was performed in a mechanized way, with 10 seeds $\mathrm{m}^{-1}$, in a $0.5 \mathrm{~m}$ spacing between rows. Basic fertilization was used, from formulated 4-14-8 $\left(\mathrm{N}-\mathrm{P}_{2} \mathrm{O}_{5}-\mathrm{K}_{2} \mathrm{O}\right)$ at a dose of $350 \mathrm{~kg} \mathrm{ha}^{-1}$, in addition to the application of $60 \mathrm{~kg} \mathrm{ha}^{-1}$ of nitrogen in the crop row cover at 40 days after crop emergence. During the

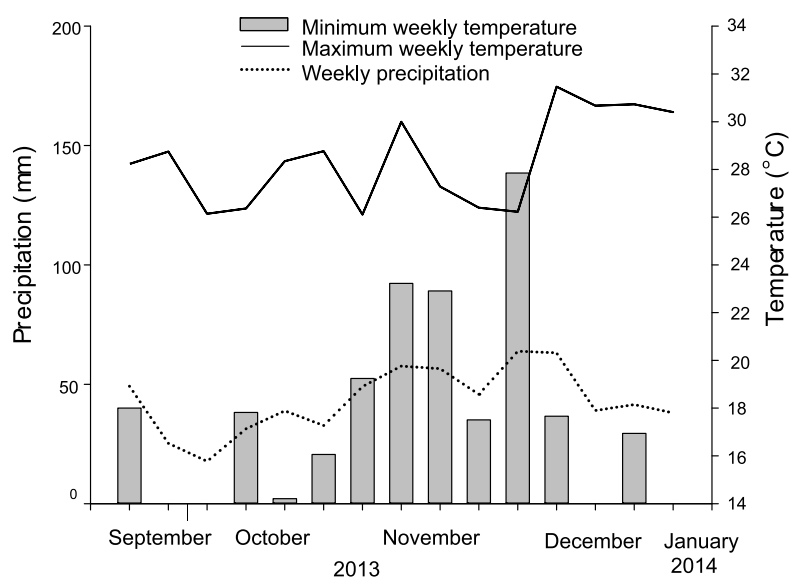

Figure 1 - Rainfall, maximum weekly temperature and minimum weekly temperature during tillage of the experiment. Viçosa, 2014.

experiment, additional irrigations were made on the dates with periods of drought (Figure 1).

The treatments were arranged in a $3 \times 4+2$ factorial arrangement, constituted by the use of three herbicides (fomesafen, fluazifop-P-butyl and their mixing) and four boom heights $(0.20,0.30,0.40$ and $0.50 \mathrm{~m})$, besides two controls referring to the plots with and without hoeing (in the clean one and in the bush). The use or not of comparison with control plots was adopted in accordance with the characteristics of each variable under study. The design adopted was in randomized block with four replications.

At 30 days after emergence of the bean plants (DAE) - when these were an average $0.30 \mathrm{~m}$ tall and two pairs of trifoliate leaves and weeds on average $0.03 \mathrm{~m}$ - herbicide spraying was carried out with a $\mathrm{CO}_{2}$ pressurized backpack sprayer, equipped with a boom with four nozzles with a TT 11002 fan type tip,

Table 1 - Results of chemical and physical analyses of the experimental area soil

\begin{tabular}{|c|c|c|c|c|c|c|c|c|c|c|c|c|c|}
\hline \multirow{2}{*}{ Soil } & $\mathrm{pH}$ & $\mathrm{P}$ & $\mathrm{K}$ & $\mathrm{Ca}$ & $\mathrm{Mg}$ & $\mathrm{Al}$ & $\mathrm{H}+\mathrm{Al}$ & $\mathrm{SB}$ & $(\mathrm{t})$ & $(\mathrm{T})$ & $\mathrm{V}$ & $\mathrm{m}$ & MO \\
\hline & $\left(\mathrm{H}_{2} \mathrm{O}\right)$ & \multicolumn{2}{|c|}{$\left(\mathrm{mg} \mathrm{dm}^{-3}\right)$} & \multicolumn{7}{|c|}{$\left(\mathrm{cmol}_{\mathrm{c}} \mathrm{dm}^{-3}\right)$} & \multicolumn{2}{|c|}{$(\%)$} & $\left(\right.$ Dag kg $\left.^{-1}\right)$ \\
\hline Podzolic & 5.6 & 5.9 & 64 & 20 & 0.8 & 0.3 & 3.3 & 2.96 & 2.96 & 6.26 & 47 & 0 & 2.6 \\
\hline \multicolumn{2}{|c|}{ Granulometry (\%) } & \multicolumn{5}{|c|}{ Clay $=43$} & \multicolumn{4}{|c|}{ Silt $=14$} & \multicolumn{3}{|c|}{ Sand $=43 \%$} \\
\hline
\end{tabular}

Analyses performed at Laboratório de Análises de Solo Viçosa, according to the methodology by Empresa Brasileira de Pesquisa Agropecuária - EMBRAPA (1997); $(\mathrm{t})=$ effective cation exchange capacity; $\mathrm{V}=$ saturation by bases; $\mathrm{m}=\mathrm{S}=$ saturation by $\mathrm{Al}^{+3}$; $\mathrm{NOM}^{2}$ organic matter (or organic material, natural organic matter). 
spaced $0.50 \mathrm{~m}$ apart, with a pressure of $246 \mathrm{kPa}$ $\left(35 \mathrm{lb} \mathrm{pol}^{-1}\right)$ and a spray solution volume of $150 \mathrm{~L} \mathrm{ha}^{-1}$. During the applications, the soil was wet, the ambient temperature was $22{ }^{\circ} \mathrm{C}$, relative humidity $70 \%$, and wind speed $4 \mathrm{~km} \mathrm{~h}^{-1}$. The meteorological data collected in the experimental area during the research are presented in Figure 1.

At the time of application, the weed community of the experimental area consisted mainly of the following species: generally known as joyweeds (Alternanthera tenella), common names include black-jack, beggarticks, cobbler's pegs, and Spanish needle (Bidens pilosa), Chelidonium majus (greater celandine; tetterwort, nipplewort, swallowwort (Chelidonium majus), several common names include gallant soldier and potato weed (Galinsoga parviflora), common names include Flax-leaf Fleabane, Wavy-leaf Fleabane and Argentine Fleabane (Conyza bonariensis), known by several common names, including picotee morning glory, ivy morning glory, and Japanese morning glory (Ipomoea nil), several common names, including red-root amaranth, redroot pigweed, red-rooted pigweed, common amaranth, pigweed amaranth, and common tumbleweed (Amaranthus retroflexus), sometimes called asthma-plant (Euphorbia hirta) and Common names include crabgrass, finger-grass, and fonio (Digitaria horizontalis).

At 14 days after herbicide application, weed control (\%) and intoxication of the bean plants were assessed by the visual method (\%), on a scale ranging from 0 (no control and no symptoms) to $100 \%$ (absence of weeds and dead bean plants). At 90 DAE (60 days after application), assessment was done for weeds dry matter $\left(\mathrm{g} \mathrm{m}^{-2}\right)$, number of seeds per pod (NSP), number of pods per plant (NPP), number of seeds per plant (NSP), seed weight per plant (WSP) and grain yield ( $\left.\mathrm{kg} \mathrm{ha}^{-1}\right)$ of the bean plant.

A comparison was carried out by the standard deviation for variables weeds control and bean plants poisoning. As for the other variables, the data were subjected to analysis of variance, for significant effects. Comparisons were done between averages using Tukey's test $(\mathrm{p} \leq 0.05)$ and/or Dunnett's test ( $\mathrm{p} \leq 0.05)$ (comparisons with the controls, when deemed necessary).

\section{RESULTS AND DISCUSSION}

Changing the height of the spray boom gave rise to different coefficients of variation (CV\%) of the patterns: CV (coefficient of variation) of $25.76,11.18,7.41$ and $5.08 \%$ for heights $0.20,0.30,0.40$ and $0.50 \mathrm{~m}$, respectively. Approaching the target boom (height reduction) resulted in a higher concentration at the center of the distribution pattern (Figure 2). When positioned at $0.50 \mathrm{~m}$ from the target, the pattern had less variation, being the most suitable for uniform distribution of liquids to this tip in the employed conditions.

The homogeneous cover of the spray solution results in a uniform distribution, characterized by low coefficients of variation of the volume distribution both in the longitudinal direction and in the transverse direction. The transverse uniformity depends on the tip used, the overlap of the jets and the position of the sprayer nozzle boom in relation to the treatment plan (Cunha, 2007). For the flat spray tip TT 11002 , the coefficient of maximum permissible variation is $7.0 \%$ for the boom height and the pressure specified by the manufacturer, and it is $9.0 \%$ for the other heights and pressures (ECS, 1997). Thus, it is not recommended to work with the tip assessed in a height equal to or less than $0.30 \mathrm{~m}$ from the target, as already evidenced by a test conducted by Freitas et al. (2005). In this condition, the overlap of the jets will not be sufficient to achieve a good uniformity of distribution.

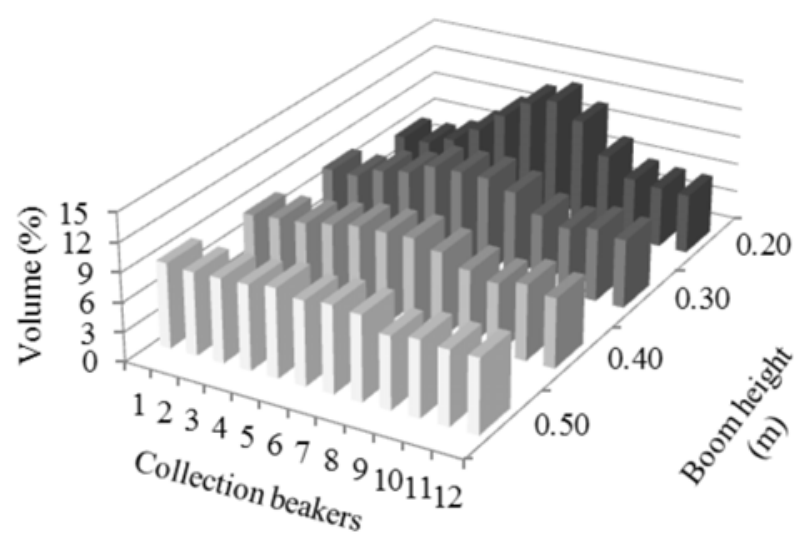

Figure 2 - Volumetric distribution patterns of the hydraulic nozzle of TT 11002 flat jet when working with overlapping. 
In the field experiment, when the herbicides were applied with boom at the height of $0.20 \mathrm{~m}$, there was no difference between treatments in the percentage of weed control (Figure 3). However, in the other heights, the fluazifop-P-butyl + fomesafen mixture promoted greater control. Most control efficiency obtained with the application of fluazifop-P-butyl and its mixture with fomesafen was observed when these herbicides were applied to the boom at the height of $0.50 \mathrm{~m}$ from the target. There was no difference in fomesafen efficiency in weed control in the different heights of application booms.

Regardless of the adopted boom height, the application of fomesafen alone and the herbicide mixture resulted in a decrease in dry matter accumulation of dicotyledons regarding the absence of tillage (Figure 4A).
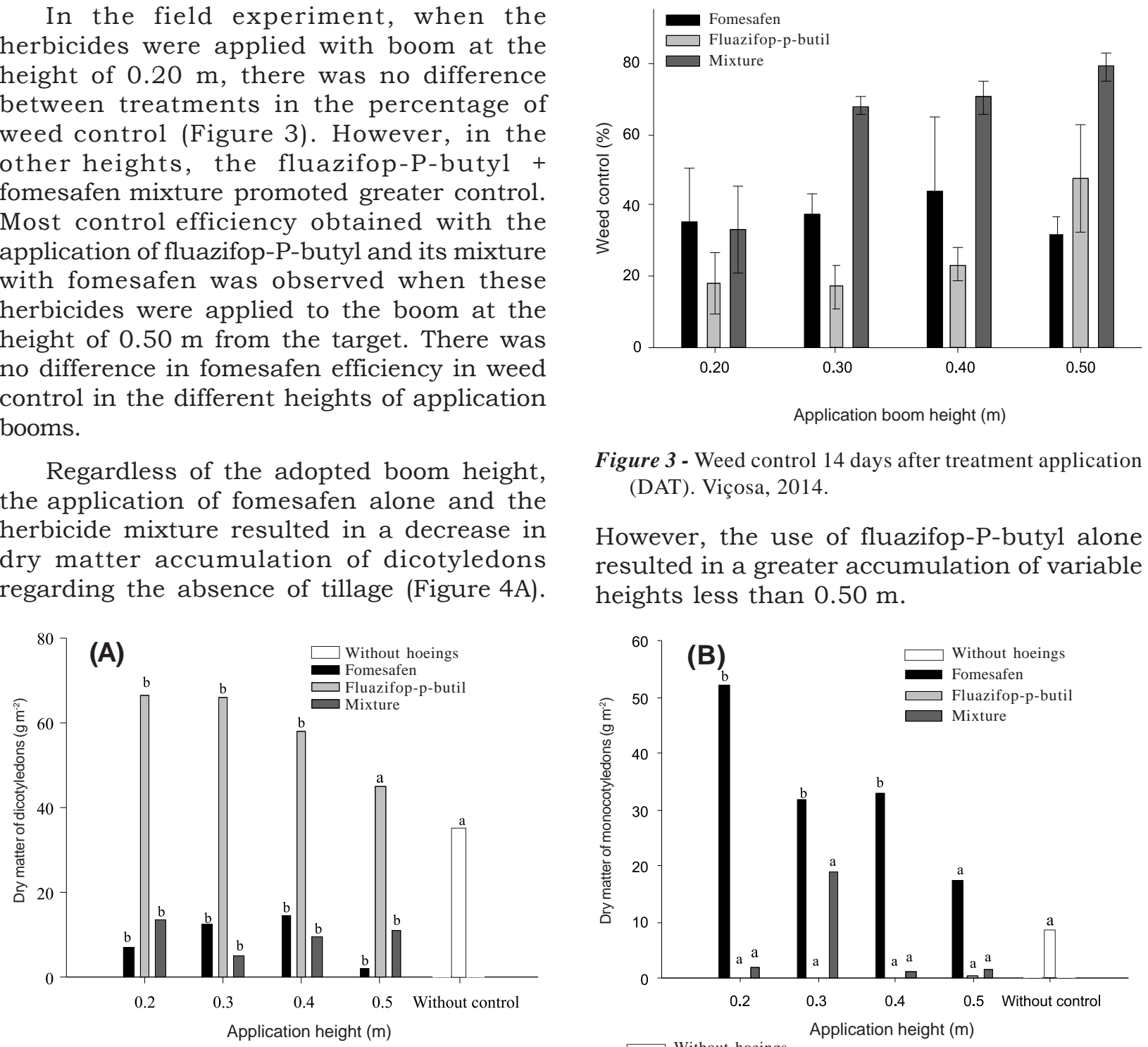

Figure 3 - Weed control 14 days after treatment application (DAT). Viçosa, 2014.

However, the use of fluazifop-P-butyl alone resulted in a greater accumulation of variable heights less than $0.50 \mathrm{~m}$.
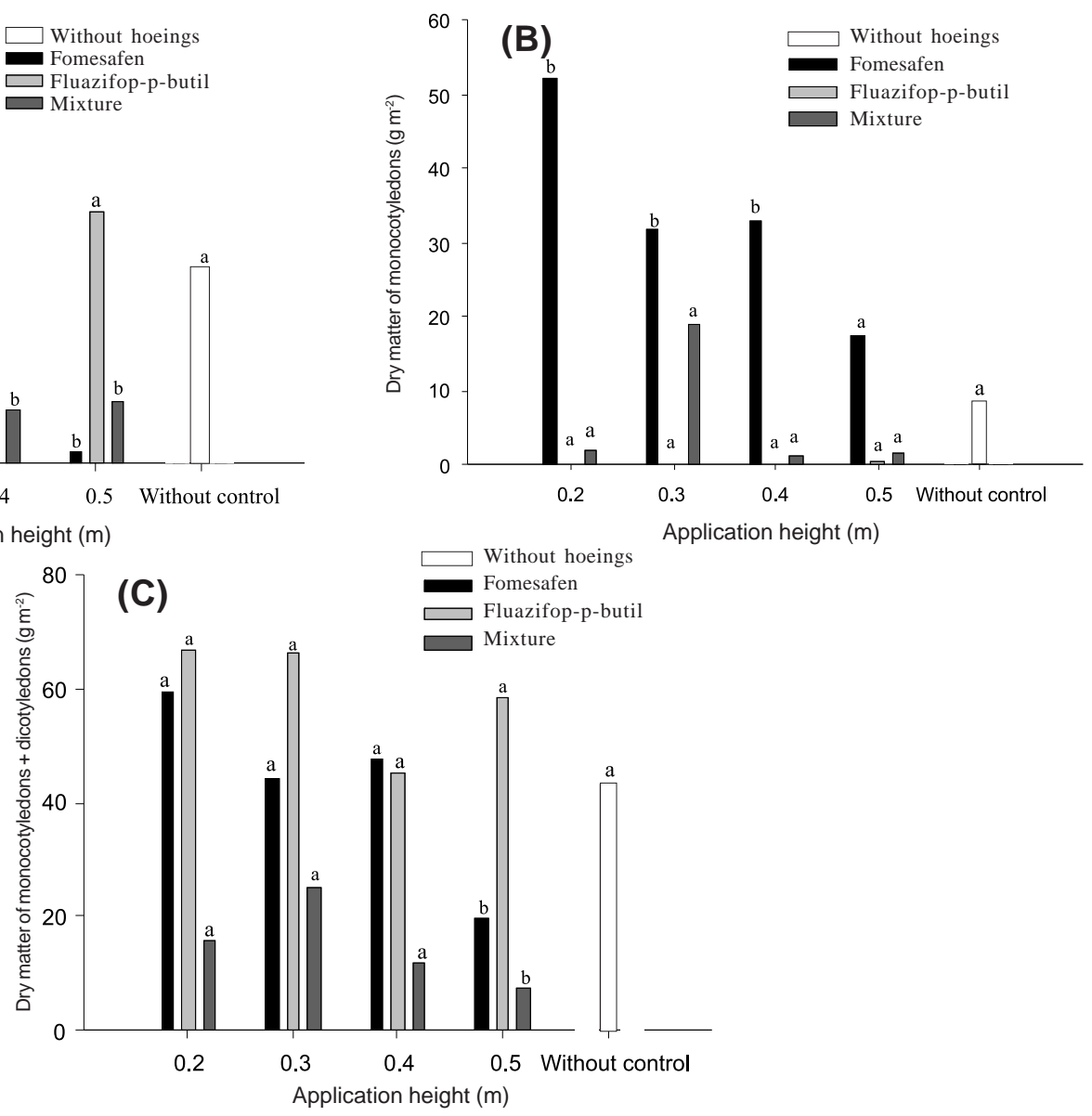

Figure 4 - Dicotyledons dry matter (A), monocotyledons dry matter (B) and monocotyledons + dicotyledons dry matter (C) under herbicides tillage assessed on the bean harvest date. Boom with an average followed by a letter different from the control differs from this one by the Dunnett's test $(\mathrm{p} \leq 0.05)$. 
The use of fluazifop-P-butyl alone and the mixture of herbicides did not differentiate the treatment without control in the dry matter of monocotyledons, which can be explained by the low dry matter production of monocotyledons in the treatment without control (Figure 4B). In the use of fomesafen alone, greater accumulation of dry matter of monocotyledons is also seen at heights less than $0.50 \mathrm{~m}$.

The accumulation of (dicotyledonous and monocotyledonous) weeds dry matter was only reduced when the boom was placed at $0.50 \mathrm{~m}$ from the target and when fomesafen alone and the mixture of the two herbicides were used, the latter being the treatment that promoted greater reduction (Figure $4 \mathrm{C}$ ).

Using the application boom at heights below that recommended by the manufacturer of this tip can result in the accumulation of weed dry matter with considerable values, and the interaction with species such as Brachiaria plantaginea, Digitaria sanguinalis, Cenchrus echinatus, Digitaria sanginalis, Acanthospermum hispidum, Bidens pilosa and Galinsoga parviflora, among others, which are weeds with a high potential for competition with bean plants and can cause major losses of yield (Aguyoh \& Masiunas, 2003).

Visual symptom of intoxication due to the application of fluazifop-P-butyl was not noticed (Figure 5). This is because there is a very big difference in tolerance between species of

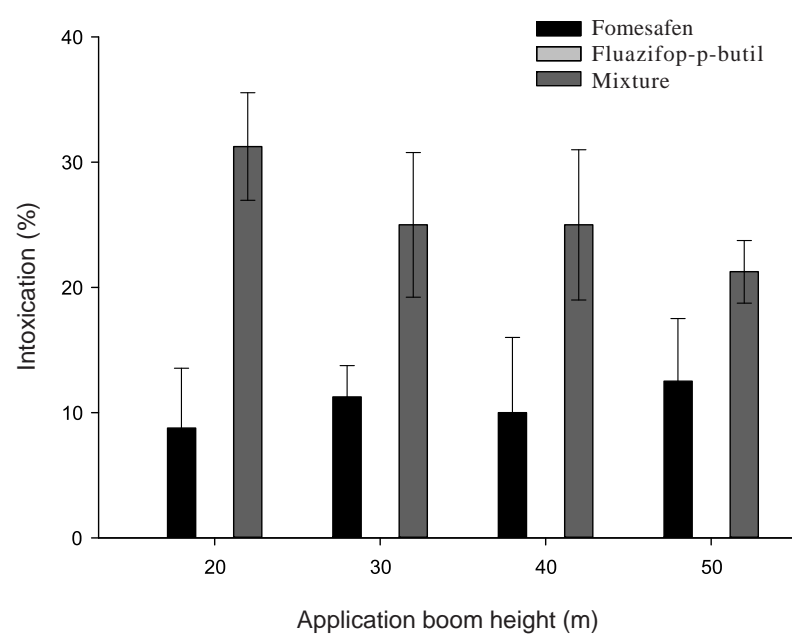

Figure 5 - Bean plants intoxication (\%) at 14 days after treatment application (DAT). Viçosa, 2014. grasses and broad-leaved to herbicides belonging to the group of ACCase (Acetyl-CoA carboxylase) inhibitors (Silva \& Silva, 2007). However, the application of fomesafen resulted in low poisoning, regardless of the application height, with chlorotic spots on the leaves with shape and intensity of the spray droplets and corrugation of the leaf surface. Bailey et al. (2003) have observed poisoning in bean plants caused by applications with fomesafen. According to Wilson (2005), bean tolerance to fomesafen increases as the bean plants go from the first trefoils to the third one. However, normally herbicide application has been made in the first bean plant developmental stages, due to less development of weeds and hence the best results in control, as performed in this study.

The application of the mixture of herbicides increased bean plant poisoning symptoms, being greater in height of $0.20 \mathrm{~m}$ compared to that recommended by the manufacturer: $0.50 \mathrm{~m}$ (Figure 5). The toxicity observed by applying the commercial mixture fluazifop-P-butyl + fomesafen can be attributed to the synergistic effect that can occur when two formulations are mixed in a tank (Wehtje, 2008).

A significant effect was seen only for comparison between tillages for the variables: number of seeds per pod, number of pods per plant, number of seeds per plant and seed weight per plant. The absence of hoeing resulted in reduction of values in all variables. The weed competition resulting from applying fluazifop-P-butyl and fomesafen alone provided a reduction in the number of seeds per pod, number of seeds per plant and seed weight per bean plant, while the number of pods per plant was similar to the control (Table 2). This fact can be attributed to the lower spectrum of action of each herbicide in isolated application, as fluazifop-P-butyl is exclusively graminicide and fomesafen has greater control over dicotyledonous species. In this way, greater presence of weeds was observed in plots treated with these herbicides applied alone (Figure 4).

There was an interaction between the factors weed tillage and application height for the yield of bean grains (Table 3). In comparing the different heights of booms in each tillage, 
Table 2 - Number of seeds per pod (NSP), number of seeds per plant (NSP), number of pods per plant (NPP) and weight of seeds per plant (WSP) of the bean plant under different weed chemical tillage systems. Viçosa, 2014

\begin{tabular}{|l|l|l|c|c|}
\hline \multicolumn{1}{|c|}{ Tillage } & NSV & NSP & NVP & PSP $(\mathrm{g})$ \\
\hline Hoeing & $6.53 \mathrm{~A}$ & $59.73 \mathrm{~A}$ & $9.18 \mathrm{~A}$ & $14.93 \mathrm{~A}$ \\
\hline Without hoeings & $3.45 \mathrm{~B}$ & $21.39 \mathrm{~B}$ & $6.27 \mathrm{~B}$ & $5.58 \mathrm{~B}$ \\
\hline Mixture & $6.20 \mathrm{~A}$ & $55.26 \mathrm{~A}$ & $9.88 \mathrm{~A}$ & $13.82 \mathrm{~A}$ \\
\hline Fomesafen & $5.39 \mathrm{~B}$ & $48.38 \mathrm{~B}$ & $8.93 \mathrm{~A}$ & $12.10 \mathrm{~B}$ \\
\hline Fluazifop-P-butyl & $4.93 \mathrm{~B}$ & $41.55 \mathrm{~B}$ & $8.34 \mathrm{~A}$ & $10.39 \mathrm{~B}$ \\
\hline CV (\%) & 13.24 & 23.04 & 17.98 & 23.04 \\
\hline
\end{tabular}

Means followed by different letters in the column differ by Dunnett's test $(\mathrm{p} \leq 0.05)$.

Table 3 - Grain yield ( $\mathrm{kg} \mathrm{ha}^{-1}$ ) of the bean plant under different weed chemical tillage systems and different application boom heights. Viçosa, 2014

\begin{tabular}{|l|c|c|c|c|}
\hline \multirow{2}{*}{\multicolumn{1}{c|}{ Tillage }} & \multicolumn{4}{|c|}{ Application boom height (m) } \\
\cline { 2 - 5 } & 0.20 & 0.30 & 0.40 & 0.50 \\
\hline Hoeing & $2680.00 \mathrm{~A}$ & $2680.00 \mathrm{~A}$ & $2680.00 \mathrm{~A}$ & $2680.00 \mathrm{~A}$ \\
\hline Without hoeings & $732.22 \mathrm{~B}$ & $732.22 \mathrm{~B}$ & $732.22 \mathrm{~B}$ & $732.22 \mathrm{~B}$ \\
\hline Mixture & $2154.54 \mathrm{bA}$ & $2664.75 \mathrm{aA}$ & $3224.78 \mathrm{aA}$ & $2843.80 \mathrm{aA}$ \\
\hline Fomesafen & $1609.54 \mathrm{bB}$ & $1575.05 \mathrm{bB}$ & $2156.13 \mathrm{aA}$ & $2687.02 \mathrm{aA}$ \\
\hline Fluazifop-P-butyl & $1812.40 \mathrm{bB}$ & $1841.39 \mathrm{bB}$ & $1361.74 \mathrm{bB}$ & $2577.77 \mathrm{aA}$ \\
\hline CV (\%) & & & 26.53 & \\
\hline
\end{tabular}

Means followed by different lowercase letters on the row differ by Tukey's test ( $\mathrm{s} 0.05$ ), and by uppercase letters in the column differ by Dunnett's test $(\mathrm{p} \leq 0.05)$.

it was noted that there was a downward trend in yield as the boom approached the target. The mixture of herbicides showed the best results when it was used above $0.30 \mathrm{~m}$, confirming the study by Freitas et al. (2005), who claim that better distributions patterns are obtained for this tip at heights over $0.30 \mathrm{~m}$. Yield variations observed with the change of the boom height are attributed to increased competition between crop and weeds, arising from the poor shape of the herbicide distribution pattern in the area.

The absence of hoeing decreased by $72.67 \%$ the crop yield in relation to the manual hoeing treatment, similar to that found by Wilson et al. (1993), Salgado et al. (2007) and Borchartt et al. (2011). Regardless of the chemical tillage adopted, yield did not differ from the control when the boom was placed at $0.50 \mathrm{~m}$ (Table 3), which was not expected, since the weed community was composed of monocotyledonous and dicotyledonous plants and herbicides fomesafen and fluazifopP-butyl have a wider spectrum of action on broad-leaved and narrow-leaved, respectively. However, the isolated application of herbicides at the height of $0.50 \mathrm{~m}$ was enough to control part of the weeds and the bean plants had crop control over the other weeds.

Bean plants crop is accomplished in part by small farmers using backpack sprayers as the primary means for applying herbicides. The results indicate that the efficiency of weed control and, consequently, crop yield are dependent on the adopted application technology. In this case, the application of herbicides fluazifop-P-butyl and fomesafen at a boom height of $0.50 \mathrm{~m}$ using flat spray tip TT 11002 promotes low toxicity of crop plants and better control of weeds, and therefore provides the farmer with greater assurance of the expected yield scope.

It was concluded that the best spray solution distribution pattern is achieved at the height of $0.50 \mathrm{~m}$ from the target for the flat spray tip TT 11002 and that the use of boom heights lower than $0.50 \mathrm{~m}$ from the target may 
undermine the selectivity of the product on the crop, weed control and bean plant yield.

\section{LITERATURE CITED}

AGUYOH, J. N.; MASIUNAS, J. Interference of large crabgrass (Digitaria sanguinalis) with snap beans. Weed Sci. v. 51, n. 2, p. 171-176, 2003.

BAILEY, W. A. et al. Weed control and snap bean (Phaseolus vulgaris) response to reduced rates of fomesafen.

Weed Technol., v. 17, n. 2, p. 269-275, 2003.

BAUER, F. C.; RAETANO, C. G. Distribuição volumétrica de calda produzida pelas pontas de pulverização XR, TP e TJ sob diferentes condições operacionais. Planta Daninha, v. 22, n. 2, p. 275-284, 2004.

BORCHARTT, L. et al. Períodos de interferência de plantas daninhas na cultura do feijoeiro-comum (Phaseolusvulgaris L.). R. Ci. Agron., v. 42, n. 3, p. 725-734, 2011

\section{COMPANHIA NACIONAL DE ABASTECIMENTO -} CONAB. Disponível em : <http://www.conab.gov.br/ OlalaCMS/uploads/arquivos/14_05_28_15_58_31_revista_ mai_2014_versao_para_internet.pdf $>$. Acesso em: 13 jun. 2014 .

CUNHA, J. P. A R.; RUAS, R. A. A. Uniformidade de distribuição volumétrica de pontas de pulverização de jato plano duplo com indução de ar. Pesq. Agropec. Trop., v. 36, n. 1, p. 61-66, 2006

CUNHA, J. P. A. R. Análise da distribuição volumétrica de pontas de pulverização hidráulicas de jato plano. R. Ci. Agr., v. 31, n. 1, p. 234-239, 2007.

CUNHA, J. P. A. R.; SILVA, R. A. M. Uniformidade de distribuição volumétrica de pontas de pulverização em função da pressão de trabalho e altura da barra. Biosci. J., v. 26, n. 1, p. 52-58, 2010.

EUROPEAN COMMITTEE FOR STANDARDIZATION ECS. Agricultural and forestry machinery- Sprayers and liquid fertilizer distributors- Environmental protectionPart 2: Low crop sprayers- prEN 12761-2: 1997. Brussels: CEN, 1997. 17 p.
FREITAS, F. C. L. et al. Distribuição volumétrica de pontas de pulverização turbo teejet 11002 em diferentes condições operacionais. Planta Daninha, v. 23, n. 1, p. 161-167, 2005.

JAKELAITIS, A. et al. Atividade residual no solo da mistura comercial dos herbicidas fluazifop-p-butil e fomesafen utilizados no cultivo convencional e direto do feijoeiro. Planta Daninha, v. 24, n. 3, p. 533-540, 2006.

MACHADO, A. F. L. et al. Misturas de herbicidas no manejo de plantas daninhas na cultura do feijão. Planta Daninha, v. 24, n. 1, p. 107-114, 2006.

MANABE, P. M. S. et al. Características fisiológicas de feijoeiro em competição com plantas daninhas. Biosci. J., v. 30, n. 6, p. 1721-1728, 2014.

NÓBREGA, R. S. Um pensamento crítico sobre classificações climáticas: de Köppen até Strahler. R. Bras. Geogr. Fís., v. 3, n. 1, p. 18-22, 2010.

PERECIN, D. et al. Padrões de distribuição obtidos com bicos Twinjet em função da altura e do espaçamento entre bicos.

R. Eng. Agríc., v. 14, n. 1, p. 19-30, 1994.

SALGADO, T. P. et al. Interferência das plantas daninhas no feijoeiro carioca. Planta Daninha, v. 25, n. 3, p. 443-448, 2007.

SILVA, A. A.; SILVA, J. F. Tópicos em manejo de plantas daninhas. Viçosa, MG: Universidade Federal de Viçosa, 2007. 106 p.

SILVEIRA, H. M. et al. Características fotossintéticas de cultivares de mandioca tratadas com fluazifop-p-butyl e fomesafen. R. Agro@mbiente On-line, v. 6, n. 3, p. 222-227, 2012.

WEHTJE, G. Synergism of dicamba with diflufenzopyr with respect to turfgrass weed control. Weed Technol., v. 22, n. 4, p. 679-684, 2008.

WILSON, R. G. Wild proso millet (Panicum miliaceum) interference in dry beans (Phaseolus vulgaris). Weed Sci., v. 41, n. 4, p. 607-610, 1993.

WILSON, R. G. Response of dry bean and weeds to fomesafen and fomesafen tank mixtures. Weed Technol., v. 19, n. 1, p. 201-206, 2005. 